\title{
Getting a job: finding work in the city of Rome
}

\author{
Claire Holleran
}

It was long held that there was no labour market in Rome, with the freeborn population viewed as an idle one. Carcopino, for example, described the recipients of the grain distributions as 'idlers, chronically out of work and well satisfied to be so', while Louis talked of a 'proletariat', able to 'live in idleness'. ${ }^{1}$ This idleness was supposedly facilitated by two key institutions: the grain distributions, which fed the population at the expense of the state, and slavery, which enabled the freeborn to live a life of leisure while work was undertaken by slaves and ex-slaves. Thus while the existence of wage work in Rome (and in the Roman world in general) was recognised, it was viewed as a marginal activity, spasmodic and casual in nature. ${ }^{2}$ Yet the free inhabitants of Rome could not live off public munificence alone. ${ }^{3}$ While the grain distributions were relatively generous, adequately meeting the calorific requirements of more than a single adult male, the amount distributed was not enough to feed a family, and diets still had to be supplemented with other food. ${ }^{4}$ Moreover, they were based on status rather than need and were open only to a subset of adult male citizens; the number of recipients was apparently reduced from 320,000 to 150,000 by Caesar, and fixed at just over 200,000 by Augustus in 2 BC. ${ }^{5}$ Furthermore, while slaves and freedmen may dominate the record of occupational inscriptions from Rome, this should be viewed primarily as a consequence of the particular 'epigraphic habit' of this group, rather than forming an accurate reflection of the profile of

${ }^{1}$ Carcopino (1941: 194); Louis (1927: 2).

${ }^{2}$ Most famously, see Finley (1985: 73; 185-86). For the opposite view, see now Temin (2004); (2013: 11438). Also Brunt (1980: 100) who denies that the hiring of free labour was of 'secondary importance in imperial times'.

${ }^{3}$ See, for example, Le Gall (1971).

${ }^{4}$ Garnsey (1998: 236).

${ }^{5}$ Caesar: Suet. Caes. 41.3; Dio 43.21.4. Augustus: Aug. RG 15; Suet. Aug. 40.2; Dio 55.10.1. 
the urban workforce.$^{6}$ Indeed, Augustus' failed attempt to reorganise the distribution process in order to reduce disruption clearly presupposes that the recipients worked for a living. ${ }^{7}$

In reality, the vast majority of the freeborn inhabitants of Rome had to work to support themselves, regardless of the grain distributions and the presence of slaves in the city, and there is much to suggest that there was a functioning labour market in Rome. In the most basic terms, a labour market is characterised by the buying and selling of labour. Workers offer their labour to employers in exchange for rewards, primarily wages or salary, which differ depending on the roles undertaken. ${ }^{8}$ For a labour market to function effectively, workers must be free to change their location and their occupation, and should be paid relative to their skills. ${ }^{9}$ With these criteria in mind, is it legitimate to speak of a labour market in Rome? Were workers free to move between occupations and were they paid for their labour, commensurate with their skills?

Although much of the population may have been relatively static, there was certainly some movement of people within the Roman empire, and the city of Rome in particular was a centre of migration. ${ }^{10}$ Free workers were also able to move between occupations, since there were no hereditary limitations or restrictions imposed by guilds or the state, at least not until late antiquity. ${ }^{11}$ Although clearly intended to be humorous, we might think, for instance, of the Pompeian graffito about a person who had worked as an innkeeper, a 'clay worker', a dealer in salted fish, a baker, a farmer, a maker of bronze trinkets, a retailer, and a dealer in jugs. ${ }^{12}$ To identify the presence of a labour market, however, we also need to identify exchange between employers and workers, with

${ }^{6}$ Joshel (1992: 46-49).

7 Suet. Aug. 40.2; See also Tac. Hist. 1.86 for misery caused by a flood in Rome in AD 69; the people of the city faced famine not only because of a lack of supplies, but also because of a lack of employment.

${ }^{8}$ Other potential rewards include power and status. See, for example, Kalleberg and Sorensen (1979: 351).

${ }^{9}$ See Temin (2013: 115) for the fulfilment of these two conditions as key to a functioning labour market.

${ }^{10}$ For mobility in general, see e.g. Scheidel (2004); (2007: 50). For migration to Rome, see e.g. Holleran (2011: 159-60), with further refs.

${ }^{11}$ In general, see Jones (1973: 1050-51); see also 699-700 (bakers); 702 (pork butchers); 861 (urban craftsmen); 594-5 (civil servants); 835 (workers in state factories); 838 (miners) all with further references.

${ }_{12}$ CIL IV 10150: [cum] de[d]uxisti octies tibi superat ut (h)abeas sedecies coponium fecisti cretaria fecisti salsamentaria fecisti pistorium fecisti agricola fuisti aere minutaria fecisti propola fuisti laguncularia nunc facis si cummu(m) linx<s>e<e>ris, consummaris omnia: Peña and McCallum (2009: 63). The joke would surely only work if changing occupations were possible. 
workers being paid for their labour relative to their skills. Anecdotal evidence drawn from ancient literature indicates that the hiring of labour was relatively commonplace in the Roman world, with hired workers known as mercennarii - a term which derives from merces (pay or wage) and thus clearly implies payment - and operarii. ${ }^{13}$ In literary and legal sources, hired workers appear primarily as agricultural labours, but they are also mentioned in a more urban context, as domestic workers, porters, muleteers, in construction, in a bakery, and in a variety of miscellaneous tasks. ${ }^{14}$

Perhaps the most telling piece of evidence for a Roman labour market, however, is the catalogue of daily wages in Diocletian's Price Edict. ${ }^{15}$ The listing of different wages for a wide variety of different tasks, ranging from skilled work such as cabinet-making (50 denarii a day, with maintenance) to unskilled work such as farm labouring ( 25 denarii a day, with maintenance), rather presupposes a market for labour. ${ }^{16}$ Labour here is classified as a commodity like any other, and wages are adjusted to reflect the different levels of skill required for particular tasks. These are maximum prices, so do not necessarily signify an integrated labour market across the Roman world, but the presence of wages within the price edict certainly points to the importance of hired labour. ${ }^{17}$ Some contracts of employment between free workers and employers also survive from the Roman empire, such as those from the Dacian gold mines and the imperial quarries at Mons Claudianus in Egypt. $^{18}$

Slavery then was not incompatible with the hiring of labour in Rome or elsewhere. In fact, although their mobility may have been somewhat constrained by their legal status, slaves

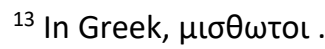

${ }^{14}$ As agricultural workers: e.g. Var. R. 1.17; in a domestic context, see, for example, the hired servant Corax in Petronius' Satyricon (see esp. Petr. 117.11; also Dio Chrys. Or. 7.114; Marcian. Dig. 48.19.11.1); as a porter: Apul. 1.7; as muleteers: Fest. p.258M; in construction, see Ven. Dig. 45.1.137.3; in a bakery: Plin. Ep. 10.74.1; miscellaneous tasks, e.g. guarding a corpse, Apul. Met. 2.21-30, discussed further below; throwing dice for a man with gout in his fingers, Hor. Sat. 2.7.15-18; see also Plut. De vitando aere alieno 6; Epictetus, Dialogues 3.26. In general, Paul. Dig. 47.2.90.

${ }^{15}$ Explored in this volume by Groen-Vallinga and Tacoma.

${ }^{16}$ Not all payment is in the form of daily wages; some payments were made per action or per task (e.g. per animal for the clipping and preparing of hooves, or per man for a barber; per pupil for a teacher; per item for a fuller etc.).

${ }^{17}$ The introduction to the edict (pr.15-17) allows for variations in prices between places.

${ }^{18}$ Cuvigny (1996). 
themselves were a part of the labour market. ${ }^{19}$ They could either be hired out by their owners, or hire themselves out, paying a part of their daily earnings to their owners. ${ }^{20}$ In this context it is worth noticing Chrysippus' definition of a slave as a 'perpetuus mercennarius' ${ }^{21}$. Slave, free, and freed were all part of the same functioning labour market, and must often have worked alongside each other, although it is difficult to gauge the relative proportion of slave, freed, or free workers in the labour force (and in the population of Rome in general). ${ }^{22}$

Many of the free workers in Rome will have worked independently, be it in retail, manufacturing, or the service industry, but others must have found work on the labour market. The structure and organisation of this market, however, remains unclear, as does the overall proportion of workers in Rome (and in the Roman world more broadly) who were employed by others. This paper marks the beginning of a wider project exploring the labour market of Rome in its entirety, although here the focus is on one particular aspect: the finding of labour. For a labour market to function, employers and workers must have some effective means of finding each other, and this paper considers the dissemination of information about employment opportunities in the city. To a certain extent, the method used must have depended on the type of work concerned. For one-off unskilled roles, for example, ad hoc methods would probably have sufficed, while for short-term but more regular roles, such as in construction, a more reliable and organised system must have been in place; the finding of skilled labour must also have been a more complicated process. The following discussion does not aim to be definitive but reflects some initial thoughts on how labour might be found and engaged. The paper considers four distinct but overlapping methods of finding labour in an urban context: advertising, congregation, networks, and clientelism.

${ }^{19}$ e.g. Plaut. Vid. 25; Col. 1.pr. 12; Sen. Ben. 7.5.3; Dig. 19.2.42-43, 45.1, 48.1, 60.7; 32.73.3; 47.5.1.5; P.Wisc. 16.5. See also Athens: Davies (2007: 354-55).

${ }^{20}$ e.g. Lab. Dig. 19.2.60.7; Col. 1.pr. 12.

${ }^{21}$ Sen. Ben. 3.22.1

${ }^{22}$ See, for example, Scheidel (2005: 64-67) for a discussion of the difficulties of estimating the number of slaves in Rome and in Roman Italy. Also Scheidel (2012: 91-92). 


\section{Advertisement}

The simplest way to advertise a potential job opportunity would have been orally. A character in Apuleius' Metamorphoses, Thelyphron, for example, tells a story which begins with him running out of money in Larissa in Thessaly. He wanders about looking for work and when he comes to the forum he finds an old man standing on a stone, making a public announcement that he is looking for somebody to guard a corpse for an agreed fee ${ }^{23}$. This is fiction and the task itself may appear unusual (although the protection of corpses from witches may have been felt to be particularly necessary in Thessaly), but this part of the story at least appears plausible, if not what happens afterwards ${ }^{24}$ Criers were used in streets and fora as a means of spreading information in urban centres, informing people about lost or stolen property or runaway slaves ${ }^{25}$, and perhaps also about employment opportunities. This would be a quick, cheap, and effective way of finding workers, particularly for occasional and short-term tasks.

Written advertisements for work are another possibility, but are less probable than oral advertisements; the latter give immediate results, while the former would only be useful if workers were required for longer-term projects at some point in the future. Ideally, potential workers would also need to be literate. It is worth noting that although advertisements abound on the walls of Pompeii, offering goods, services, rental units, rewards for the return of stolen items, and electoral recommendations, to the best of my knowledge no work opportunities are offered. ${ }^{26}$ Oral advertisements are likely to have been more effective, but while these were perhaps important at an individual level and may have played a significant role in the labour market of smaller

\footnotetext{
${ }^{23}$ Apul. Met. 2.21.
}

${ }^{24}$ In Apuleius' novel, the corpse is reanimated and describes how witches put Thelyphron in a deep sleep and cut off his nose and ears, replacing them with wax (Apul. Met. 2.21-30). Thessaly was particularly connected with witches in Latin literature: Ogden (2001: 143-47).

25 e.g. Dio Chrys. Disc. 7.123.

${ }^{26}$ For example, rental inscriptions: CIL IV 138; 1136; rewards for return of stolen items: CIL IV 64; electoral recommendations: see the detailed study of Mouritsen (1988). 
communities, particularly for one-off short-term roles, overall, it is difficult to know how significant such means of engagement would have been in a city the size of Rome.

\section{Congregation}

A more efficient method would be for workers to congregate in particular areas, enabling employers and potential employees to find each other quickly and effectively. Oral advertisements could then reach their intended audience immediately. This is a practice with a long history, stretching from antiquity up to the present day, where contemporary studies in the United States document workers waiting on street corners of busy intersections, in squares, in parks, and in car parks; most jobs offered to contemporary workers are in construction, gardening, and painting. ${ }^{27}$ In the Roman world, the most famous example of this practice must be the parable of the vineyard workers in the gospel of Matthew, a story based around the idea that potential workers could be found congregating in the agora waiting to be hired ${ }^{28}$. The vineyard owner returns repeatedly throughout the day to hire additional workers, with the message of the parable resting on the workers' belief that they would be paid different rates based on the number of hours worked. Here, in what is presumably a small urban centre, workers are waiting in the agora, and it is probable that in many places the agora or forum acted as a sort of informal labour exchange. In Classical Athens, day labourers appear to have waited on the kolonos agoraios, the hill overlooking the agora, a place sometimes just called the $\mu$ เળิซtńpıov, or place of the hired labourers / the hiring place. It apparently became so synonymous with hiring that wage workers at Athens could also be referred

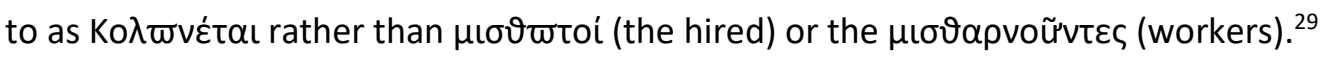

\footnotetext{
${ }^{27}$ For a brief history of this practice, from medieval England to the contemporary United States, see Valenzuela (2003: 312-314). Also see Fevre (1992: 10-13); Granovetter (1995: 121); Rosser (1997: 26) for this practice in Medieval Rouen.

28 Matt. 20.1-16.

${ }^{29}$ Pherekrates fr. 142, Harpocration p.181.16, s.v. kolonetai. See Fuks (1951); Taylor (2011: 120).
} 
Claudius (as Pontifex Maximus) ordering the withdrawal of slaves and operarii from the forum before offering up supplication from the rostra may hint at day labourers waiting there to be hired. ${ }^{30}$ In such a large city, however, it is unlikely that one single place sufficed, and the size of ancient Rome probably encouraged specialisation, with the place of congregation depending upon the type of work sought. ${ }^{31}$ Wetnurses, for example, may have been hired from the columna lactaria in the Forum Holitorium, where Festus says that infants who needed milk were taken, although this is the only mention of this location and it may also have been the place where feeding took place, rather than solely a point of hiring. ${ }^{32}$ According to Pliny the elder, cooks used to wait in the macellum in Rome to be hired. ${ }^{33} \mathrm{He}$ claims that by his own time this practice was confined to the past, as households now included cooks among their slaves, but Pliny is making a moralising point here and in any case, this may not have been true of everybody in Rome. Some households may still have hired cooks for special occasions; congregating in the macellum would make sense, as a potential employer could then pick up a cook along with provisions for the meal.

In a similar way, construction workers often congregate in the car parks of DIY stores in contemporary cities in the United States, enabling employers to pick up materials and labour in the same place. ${ }^{34}$ In Rome also, those looking for work in the building trade, particularly as unskilled labourers, may have waited in places linked to the importation, manufacture, or storage of building materials. Lumber yards and timber merchants, for example, appear at one time to have been concentrated in an area in the Aventine district. According to Livy, a porticus was built in $192 \mathrm{BC}$ outside the Porta Trigemina inter lignarios (among the woodworkers or dealers in (fire)wood; Liv.

\footnotetext{
${ }^{30}$ Suet. $\mathrm{Cl}$. 22. This was in response to the sighting of a bird of ill-omen on the Capitol. My thanks to Rens Tacoma for alerting me to this reference.

${ }^{31} \mathrm{~A}$ passing reference in Plautus (Curc. 482) to men who sell themselves in the Vicus Tuscus almost certainly refers to male prostitutes rather than labourers.

${ }^{32}$ Festus $105 \mathrm{~L}=118 \mathrm{M}$. Palmer (1997: 102) relates this to the Punic cult of milk-offerings, rather than wet nursing, and he also suggests that the monument was destroyed to make way for the Theatre of Marcellus.

${ }^{33}$ Plin. Nat. 18.28.108. Plautus, with the action ostensibly set in Athens, describes the hiring of cooks from a forum coquinum: PI. Aul. 406-8; Merc. 741-82; Pseud. 790-825. The hiring of cooks is a classic comic motif, with cooks commonly portrayed as boastful and untrustworthy.

${ }^{34}$ Valenzuela et al. (2006); Valenzuela (2003: 319).
} 
35.41.10), while a Vicus Materiarius (street of the timber merchants) is also attested in this area (CIL VI 975). ${ }^{35}$ Marble must also have been unloaded in this district, since state tabularii were based here, recording imports of imperial marble (CIL VI 301; 410). ${ }^{36}$

Somewhat more tentatively, Coarelli has suggested that an open area on the slopes of the Piccolo Aventino depicted on the Severan Marble Plan of Rome was a brick storage area, linked perhaps to figlinae and tegularia alongside. ${ }^{37}$ Many bricks also came down the Tiber from brick yards in the Tiber Valley, and these may have been distributed from further up the river. ${ }^{38}$ As Graham suggests, it is probable that particular areas in Rome specialised in the unloading and storage of particular commodities, enabling the collection of taxes and customs duties. ${ }^{39}$ Furthermore, heavy building material such as marble and brick may have required particular dock facilities, such as ramps, pulleys, cranes and so on, and therefore came into the city regularly at the same place, enabling potential construction workers to know where to wait.

Those seeking work as porters most probably also waited in such areas, at the docks, or around the gates, where goods came into Rome. ${ }^{40}$ The Area Carruces, for example, located just outside the Porta Capena, may have been an area where carts were parked and unloaded before produce was carried into the city, and would have been a logical place for porters to gather. ${ }^{41}$ In Milan ${ }^{42}$ and in

${ }^{35}$ Meiggs (1980: 186); Rodríguez Almeida (1984: 33); Holleran (2012: 66). See Ulp. Dig. 32.55.pr for a distinction between lignum as primarily firewood, and materia as timber for building.

${ }^{36}$ A dealer in marble (negotiator marmorarius: CIL VI 33886) was also based in the horrea Galbana, where nineteenth-century excavations revealed a considerable quantity of worked and unworked marble. Lanciani (1897: 533-4); Holleran (2012: 75-6).

${ }^{37}$ FUR $2 \mathrm{a}$ and $2 \mathrm{~b}$. A Renaissance drawing of the now lost fragment $2 \mathrm{~b}$ depicts an open area labelled 'NAVELEMFER'; Coarelli (2000: 376-78) argues that rather than depicting a 'lower navalia' (navale inferius), navalia here is a colloquial expression for brickyard (cf. CIL III 11382) and the legend should be read as Navale M(arci) Fer[ocis]. For associated figlinae and tegularia, see FUR 201. Discussed also in Graham (2005: 109-10).

${ }^{38}$ Graham (2005). See also p. 111 for the 'Tor di Nona', a mole that jutted into the Tiber near the Campus Martius, as a possible specialised dock for bricks.

${ }^{39}$ Graham (2005: 110-11). For a discussion of customs duties in Rome, see Holleran (2012: 89-92).

${ }^{40}$ See also Broughton (1938: 56-57) for groups of porters based in specific locations in eastern cities, organised in associations, e.g. the porters of the harbour at Cyzicus. At Portus in the fourth century, a corpus of saccarii had a monopoly on the movement of goods; if a private citizen was found to have employed his own porters, a fifth of his wares was confiscated, although this probably reflects increased controls in late antiquity rather than earlier practice (C.Th.14.22.1; Sirks (1991: 258-59)).

${ }^{41}$ Holleran (2012: 89). 
Fossombrone ${ }^{43}$ at least, collegia of dealers or drivers of mules (collegium iumentariorum) were also based at city gates. ${ }^{44}$ At Cales, cisiarii (carriage drivers) were associated with city gates ${ }^{45}$.

Furthermore, Rome was a large enough city to have specialised quay areas and storage facilities for particular commodities or goods, as well as specialised markets. There was, for example, a horrea chartaria (paper warehouse), a horrea piperataria (pepper warehouse), a portus vinarius, a portus olearius (facilities specialising in wine and oil respectively), and numerous commercial fora (e.g. Forum Boarium, Forum Suarium etc), as well as some clustering of trades in the city. ${ }^{46}$ Potential workers who wished to find work within the movement, manufacturing, or sale of particular goods could then have congregated in particular areas.

Contemporary studies, particularly in the United States, indicate that congregating in particular places is a cheap and potentially effective way of employers and employees finding each other, although it remains a relatively marginal practice. Indeed, the vast majority of those who find work in this way are day labourers, and these studies demonstrate the fluidity of the day labourer market and the changing composition of workers. However, within the apparent randomness of the system, there is space for relationships to flourish and trust to develop between workers and employees, with some day labourers being hired repeatedly by the same employer. ${ }^{47}$ In Rome also, it is probable that while working relationships between day labourers and employers may have remained casual, being negotiated on a daily or short-term basis, the hiring of workers was not entirely random, but was based on reputation and personal relationships. The building trade in particular was probably organised into small 'firms', which may have then hired day labourers on a

${ }^{42}$ CIL V 5872.

${ }^{43}$ CIL XI 6136.

${ }^{44}$ MacMullen (1974: 70; 175). Further inscriptions from Verona also record iumentarii Port(ae) lov(iae). My thanks to Scott Perry for this reference and for sharing with me his paper, 'The go-between(s): transportation workers, status, and burial in Roman Italy', delivered at the AAH Annual Meeting, Columbus, May 2013. For the potential role of collegia in the allocation of work, see below.

${ }^{45} \mathrm{CIL} \times 4660$ (here gisiarii).

${ }^{46}$ Holleran (2012: 71-72; 78-80; 93-97). On the clustering of trades in general, see Holleran (2012: 51-60)

${ }^{47}$ Valenzuela (2003: 319); Valenzuela et al. (2006: 9). 
casual basis; regular hiring of the same individuals must have allowed relationships to develop. ${ }^{48}$ The practice of congregating, however, may have put workers at a disadvantage when it came to negotiating payment since it would immediately be obvious to an employer that other workers were available, although this could of course work both ways. ${ }^{49}$

\section{Networks}

The development of such relationships points to the importance of networks in finding employment, a phenomenon that has long been the subject of research in the social sciences. Granovetter, for example, has argued extensively that social ties play a key role in finding employment. In his influential analysis, he distinguished between 'strong ties' between close friends and 'weak ties' between acquaintances, contending that weak ties are more important in the spread of new information about employment opportunities. Since close friends tend to move in the same circles, they share the same information, while acquaintances move in different circles and have access to different information, thus acting as bridges between groups. ${ }^{50}$ Burt reformulated this argument to suggest that ties between groups can be strong or weak, but the important point is that these ties act as a bridge for information, through what he terms 'structural holes' in a network. ${ }^{51}$ In both these analyses, individuals with ties to multiple groups are at a particular advantage when it comes to gleaning information about potential employment opportunities. If we apply this analysis to Rome, an inhabitant of the city might be a member of numerous networks, based on factors such as family links, neighbourhoods, religious practices, trade, ethnicity, and (for migrants at least) place of origin, many of which would potentially overlap; comparative evidence would suggest that these networks were all potentially important for the transmission of information about work opportunities.

\footnotetext{
${ }^{48}$ Ven. Dig. 45.1.137.3. See DeLaine (1997: 199) for small firms and the hiring of day labourers. Also DeLaine (2000: 132).

${ }^{49}$ See Plaut. Pseud. 804-9. Also Cic. Brut. 257 discussed above. In comparative terms, see Granovetter (1995: 121).

${ }^{50}$ Granovetter (1973); (1983); (1995); (2005). See also Yakubovich (2005). The advantages gained from social networks are also sometimes referred to as 'social capital'.

${ }^{51}$ Burt (1992: 8-49, esp. 25-30).
} 
Studies of contemporary migration, for example, have demonstrated that migrant networks play an important role not only in facilitating migration in the first place, but also in assisting new migrants to find work. The monopolisation of particular trades and the residential clustering in neighbourhoods by certain ethnic or migrant groups can also help new migrants to establish themselves within communities and find work. ${ }^{52}$ Yet aside from a Jewish community based in Trastevere, Tacoma has demonstrated that there is no substantial evidence to suggest that other ethnic or migrant communities clustered together in neighbourhoods in Rome. ${ }^{53}$ Furthermore, there is no indication of the monopolisation of particular trades and industries by certain groups, although there were provincial commercial representatives based in Rome (as there were in other trading centres of Italy). ${ }^{54}$ We might think, for example, of the groups of Tyrians resident in Rome and in Puteoli, or the renting of tabernae near the forum to representatives of certain states. ${ }^{55}$ Pliny the elder talks of stationes municipiorum (municipal offices) in the Forum of Caesar ${ }^{56}$, and stationes in Rome are attested from the Eastern cities of Anazarbus, Claudiopolis, Ephesus, Heraclea, Mopsuestia, Nysa, Sardis, Tarsus, Tiberias, and Tralles, and from the Western province of Noricum. ${ }^{57}$ MacMullen suggests that new migrants could receive a welcome from such groups, enabling them to find out important information about their destination, such as where to find suitable housing, work

${ }^{52}$ See, for example, Munshi (2003) on the role of networks in finding jobs for Mexican migrants in the USA. Poros (2001) for Asian Indian migrants in London and New York (with useful general discussion and further reading). See also Marett (1989: 80) for Ugandan Asian refugees finding work in Leicester (UK) in the 1970 s through relatives and friends rather than formal labour exchanges.

${ }^{53}$ Tacoma (2014). See also Lott (2004: 22-23).

${ }^{54}$ Although see the Neapolitani citrarii in Rome (CIL VI 9258).

${ }^{55}$ For the Tyrian groups, see IG XIV 830, lines 1-19 (= OGIS, no. 595 = IGRR I 421); Lewis and Reinhold (1990: 109-10): the inscription dates to AD 174. For further discussion, see Sosin (1999). See also CIL VI 9677 for a corpus negotiantium Malacitanorum. For tabernae as headquarters at Rome, see Suet. Nero. 37.1.

${ }^{56}$ Nat. 16.236

${ }^{57}$ Anazarbus: IGUR 78; Ephesus: IGUR 26; Heraclea: IGUR 88; Mopsuestia: IGUR 24; Nysa: IGUR 162; Sardis: IGUR 85; Tarsus: IGUR 79: Tiberias and Claudiopolis: IGUR 82-83; Tralles: IGUR 84. These Greek inscriptions date primarily to the late second and third century $A D$, and were found in the area of the Via Sacra. For further details, see especially Moretti (1958); Noy (2000: 160-61); Ricci (2005: 59). See also CIL VI $250=30723$ for a dedication to the genius of Noricum by one L. Julius Bassus, a stationarius. For an interesting parallel, see the shippers based in the so-called Piazzale della Corporazioni in Ostia: CIL XIV 4.549; Lewis and Reinhold (1990: 110-11); Meiggs (1980: 283-88); Noy (2000: 161-64). On collegia of resident aliens, see also Verboven (2011). 
opportunities and so on. ${ }^{58}$ It is difficult to know how willing such groups would be to act as unofficial 'welcome committees', particularly to those of a lower social status, although they may have charged for their services. ${ }^{59}$ In short, language, ethnicity, or place of origin could be a potential point of entry into certain networks, which would primarily be composed of 'weak ties', but such factors may have been of less importance in Rome than in other historical periods or places. ${ }^{60}$

For many in Rome, including new migrants, neighbourhood networks may have been far more important in the transmission of information about employment opportunities. According to Pliny, there were 265 vici in Flavian Rome (Nat. 3.66) and although the term vici is ambiguous, a vicus probably encompassed a street and the dwelling places which adjoined it. ${ }^{61}$ If we assume a population of one million, this would give us a figure of around 3,800 inhabitants in each vicus. Of course in practice, some vici must have been more densely populated than others, and the population was unlikely to be stable, but this figure at least gives us some sense of the potential size of neighbourhoods in Rome. It is doubtful then that everybody in a neighbourhood knew each other personally, but it is probable that many of them would be connected somehow. ${ }^{62}$ People must have interacted within neighbourhoods in Rome in different ways, meeting at the water basin, frequenting the same shops and street sellers, and eating and socialising within the same bars. Within apartment blocks also, residents may have formed ties with each other; there were, for example, communal altars set up in at least some insulae. ${ }^{63}$ This is a community based above all on proximity. Many of these links will have been what Granovetter would class as 'weak ties', and it is precisely these kind of informal networks that can be beneficial in spreading information about

58 MacMullen (1974: 84-85).

${ }^{59}$ For charging, see Verboven (2011: 339), although he is referring here primarily to merchants and shippers. Some notion of 'group solidarity' (although not necessarily residential clustering, contra Gruen (2002: 263, n.45)) is perhaps hinted at by Cicero's comment (Flac. 17) about Phrygians and Mysians disrupting contiones, and Suetonius' claim (Caes. 84.5) that after the death of Caesar, groups of foreigners in Rome mourned in their ancestral fashion.

${ }^{60}$ See also Tacoma (forthcoming b).

${ }^{61}$ Lott (2004: 4; 13-18).

${ }^{62}$ Even in the crowded and constantly changing neighbourhoods of nineteenth-century London, there was some sense of community: Winter (1993: 57).

${ }^{63}$ In the insula Bolani, for example, in the $14^{\text {th }}$ Region, residents set up an image of the Bona Dea for communal acts of ritual (CIL VI 67; 65). 
potential employment opportunities; even with a transient and changing population, close proximity would enable messages to spread quickly by word of mouth. If we think of workers such as those in construction, who were organised into small work 'gangs', it would only take one member to hear about a project for the possibility of employment for the whole group to arise. ${ }^{64}$

More formal networks in vici were based in the Republic around the local cult of the lares compitales and the annual festival of the compitalia (ludi compitales), organised by local magistrates known as vicomagistri. The vici already appear to have been convenient administrative units, at least informally, but they were also linked with political violence in the late Republic, with Cicero claiming that political agitators were collected vicatim, or vicus by vicus. ${ }^{65}$ Augustus then reconfigured and formalised the neighbourhood associations, adding a new focus on the imperial regime and the lares Augusti, and assigning four vicomagistri to each vicus, many of whom appear to have been freedmen. ${ }^{66}$ These officials played a role in the organisation of the local cult, but were also concerned with matters of civic administration, such as the local administrative divisions for the census and fire prevention. ${ }^{67}$ The vicomagistri, who numbered over a thousand in the imperial period, must have formed one of the main lines of communication between the central administration and the people. ${ }^{68}$ They were perhaps also able to gather men from neighbourhoods to work on public building projects, or at the very least (given the practice of contracting building out

64 See n.41.

${ }^{65}$ According to Livy, oil and corn was distributed to the vici on occasion (e.g. in 213 BC (25.2.8) and 202 BC (30.26.5-6)), while Caesar took a census of the population of Rome vicatim (Suet. Iul. 41.3). See also Plin. Nat. 33.132.5; Sen. Dial. 5.18.1.4 for statues to Marius Gratidianus being voted vicatim in the 80s BC, and Front. Aq. 97.8 for the upkeep of public fountains organised through the vici. For Cicero and political agitators, see Att. 4.3.2.9; Dom. 129; Sest. 34; see also Dom. 54.

${ }^{66}$ Suet. Aug. 30.1; 40.2. For more on the vici and the vicomagistri, see Robinson (1992: 11-12). For the religious aspect, see Beard, North, and Price (1998: 184-87). In general, see Lott's detailed 2004 study of the neighbourhoods of Augustan Rome. See also Wallace-Hadrill (2008: 264-90).

${ }^{67}$ Census: Suet. Aug. 40.2 (cf. Suet. Iul. 41.3); Fire: Dio 55.8.6-7; see Lott (2004: 100; 230 n.124). Games and shows were also sometimes put on vicatim: Suet. Iul. 39.1; Aug. 43.1; Tac. Hist. 2.95; see also Tert. Apol. 35.2 for feasting. Augustus also dedicated statues of the gods vicatim: Suet. Aug. 57.1. For the increasing formality of the vici from the late Republic onwards and their role in civic administration, see Lo Cascio (2008: 69-76); Tarpin (2008: 52-58).

${ }^{68}$ Four vicomagistri in each of the 265 vici of Flavian Rome (Plin. Nat. 3.66) would give a total of 1,060 local officials. 
to redemptores) to disseminate information about potential employment opportunities on these projects.

Collegia were another potentially important source of information in Rome, particularly for employers. ${ }^{69}$ There are overlaps between all of these potential networks, but this is perhaps most marked in the case of collegia, associations that might be based around a neighbourhood, a shared cult, or a shared profession, and sometimes all three. ${ }^{70}$ Shared cult practices might also reflect a shared ethnicity, as with the group of Phrygians in Rome who worshipped Cybele, while Patterson has suggested that membership of a collegium would help integrate new migrants into civic life. ${ }^{71}$ All collegia, regardless of their basis, must have helped transmit information between members, but it is collegia based around shared professions that are particularly relevant for the present study. There is debate about the extent to which such collegia should be viewed as economic rather than social institutions, but they almost certainly had some economic benefits for their members. ${ }^{72}$ One of the potential benefits of occupational collegia was access to important professional information, with members able to share knowledge about techniques, markets, the supply of raw materials, and perhaps also about potential workers. ${ }^{73}$ As Hawkins has argued, the demand for goods in Rome fluctuated, as, consequently, did the demand for labour, both skilled and unskilled; short-term workers may then have been required to enable the completion of a particular order or to meet a period of high demand. ${ }^{74}$ Finding good skilled workers was a more complicated and potentially

${ }^{69}$ For a discussion of the potential role of the collegium of the fabri tignarii in organising the workforce for major imperial building projects, see DeLaine (2000: 132). For members as 'employers' rather than 'employees', see Patterson (2006: 255); also discussion in Liu (2009: 162-63), with references. See also Liu (2009: 161-212) for the mixed social and economic status of collegia centonariorum.

70 Patterson (2006: 252).

${ }^{71}$ Patterson (2006: 261-2). He draws a comparison with migration to towns in eighteenth-century England. See also Rosser (1997: 9-10) for a medieval comparison. See IGRR I 458 for a body of Phrygians devoted to Cybele; Harland (2003: 35).

${ }^{72}$ For a summary of recent scholarship on the debate about the economic role of collegia and their similarity (or otherwise) to medieval / early modern guilds, see Liu (2009: 13-18). Also Patterson (2006: 25253).

${ }^{73}$ For a potential comparison with medieval English towns, see Rosser (1997), especially 19-20 for the role of craft organisations and voluntary clubs in the negotiation of labour contracts, and 31 for such groups providing access to financial credit, primary materials, hired labour, and the market.

${ }^{74}$ Hawkins (2006); see also elsewhere in this volume. 
more expensive process than finding unskilled labourers, particularly in a large urban centre such as Rome, where workers were less likely to be known to each other ${ }^{75}$ The information networks of a collegium may have gone some way towards simplifying the process, enabling an employer to find reputable workers quickly and efficiently, and lowering the transaction costs associated with recruiting good skilled labour for short-term roles.

\section{Clientelism}

Although the households of the elite in Rome were large, with high numbers of slaves, they were not entirely closed entities, and some of the better-connected inhabitants of Rome will have had links with these households. When Tacitus (Hist. 1.4) describes the reaction to Nero's death in Rome, for example, he says that the respectable part of the common people, that is, those attached to the great houses, the clients and freedmen of those who had been condemned and driven into exile, were all roused to hope. ${ }^{76}$ Some people in Rome then were part of yet another network, and one which was probably of great economic benefit to them. Being within the patronage of an elite household in Rome brought obligations and responsibilities, but it also brought rewards, such as financial donations, gifts, food, and meals. ${ }^{77}$ Indeed, acting as a client could in itself be a way of securing an income, or at least supplementing an income, but such links are unlikely to have spread too far down the social scale in Rome ${ }^{78}$ those whom Tacitus describes as attached to the great houses were perhaps synonymous with the plebs media, and were by no means the poorest in Rome. $^{79}$

\footnotetext{
${ }^{75}$ See Liu (2009: 22-23) for the need to distinguish between larger and smaller urban centres in thinking about collegia.

${ }^{76}$ In contrast to the plebs sordida, who were interested only in the theatre and the circuses.

77 See, for example, Verboven (2002: 64-65) on the obligations of amicitia; 71-115 on gifts and presents.

${ }^{78}$ For gifts as a form of income, or at least supplementary income, as well as the argument that clients are primarily made up of the cultural elite and the 'Roman middle classes', see Verboven (2002: 104-13). See also p.11 for those involved in networks of amicitia and patronage making up at most $10-15 \%$ of the Roman population. cf. Skydsgaard (1976: 46) who argues that there were both direct links between upper and lower strata in Rome, primarily through tabernae, and indirect links through different levels of clients. For the taberna and their links with the elite, see also Purcell (1994: 660-68). See also Guilhembet and Royo (2008) for a suggestion that vertical relations existed between the elite and the inhabitants of particular districts, at least in the Republic.

${ }^{79}$ For the plebs media, see Pliny Nat. 26.3.
} 
For a select few, however, such links may have provided access to employment opportunities. Certainly Lucian suggests that in order to get a role within one of the great houses as a salaried intellectual, it was necessary to ingratiate yourself with the household as a client until such time as your services might be engaged ${ }^{80}$. It is unclear if other more prosaic jobs - for example, domestic roles such as doorkeeping, commercial roles in tabernae, or labouring work - were also distributed in this way. ${ }^{81}$ Yet although clients may have been prepared to present themselves at a daily salutatio and act as an escort, as well as offer numerous (unpaid) services, it seems less likely that they would have found themselves performing domestic tasks or labouring work for their patrons in return for direct payment in the form of wages.$^{82}$ However, a wealthy patron in Rome may have provided access to useful business networks through recommendations, as well as assisting with access to credit, and perhaps also offering opportunities for the formulation of societates, with the client providing the labour and the patron (or another) providing the necessary capital investment. ${ }^{83}$ Thus rather than providing jobs per se, being linked to one of the great houses in Rome could have provided income assistance in the form of gifts and donations, as well as assisting with the creation or expansion of a client's business interests, whatever they might have been.

Assuming a population of c. 1 million, there must have been hundreds of thousands of free workers in the city of Rome. A significant, albeit unknown, proportion of these people worked for themselves, most commonly in sectors such as retail, manufacturing, and the service industry. However, many (again the numbers are difficult to know) will have been in the employ of others,

\footnotetext{
${ }^{80}$ Merc.Cond. 10.
}

${ }^{81}$ For employment as doorkeepers, see Plut. De vitando aere alieno 6, 830b; Epictetus, Dialogues 3.26. For tabernae and links between upper and lower classes, see n.70 and 74.

${ }^{82}$ Although remuneration may have occurred indirectly, services performed by clients were free; this is the difference between a service performed as a mandatum and one performed under a contract of hired labour (locatio conductio operis/operarum): Paul. Dig. 17.1.1.4; 1.36; 19.5.13.pr; 5.22; Verboven (2002: 228; 341). The latter case (Paul. Dig. 19.5.22) refers to the cleaning and mending of clothes, however, suggesting that some of the services performed could be relatively menial.

${ }^{83}$ For recommendations linked to trading interests, see Verboven (2002: 299-300), although these are rare, reflecting the social standing of those involved. For societates, see Ulp. Dig. 17.2.5; Verboven (2002: 276; 281). See also Skydsgaard (1976: 46) for the rental of a taberna as a beneficium and the payment of rent as an officium; if this were the case, we would either have to consider tabernarii to be part of the top 10-15\% of the urban population, or accept that the patronage links with the elite in Rome spread much further down the social scale. 
and sought work through the labour market in the city. This paper has focused on some of the ways in which employers and workers might have found each other, namely through oral advertisement, congregating in suitable areas, by means of a variety of different networks, and finally, through clientelism and links to the great houses in Rome. The first two methods of engagement would be best suited to the finding of workers for short-term unskilled roles, while the latter two would probably be more useful in locating skilled workers for more long-term roles. Given the low regard in which wage labour was held in the Roman world, our written sources display little interest in the engagement of labour. Much of the evidence employed here is, therefore, anecdotal or circumstantial, and relies heavily on comparative material drawn from studies of historical and contemporary labour markets. This makes it difficult to say with any certainty how labour was engaged in Rome. Other methods than those discussed here are likely to have existed, but are even less documented. There may, for example, have been 'agents' in the city, who matched workers with employers, something Noy suggests for migrant workers. ${ }^{84}$ Comparative evidence also points to the possibility of labour contractors; these tend to be linked in particular with short-term seasonal work, gathering groups of workers who are then hired out to different employers. ${ }^{85}$ In late Republican Italy, contractors do at least appear to have been involved in the movement of labour from one place to another, as indicated by Suetonius' comment that some believed Vespasian's great-grandfather to be a contractor (a manceps operarum) for the seasonal labourers who moved annually from Umbria to the Sabine district ${ }^{86}$. It is perhaps best to conclude that there was a functioning labour market in Rome - albeit one that must have been distorted by the presence of slavery and the ability of elite households to extract services from clients through the pressures of social obligation - and that there were methods in place to ensure that employers and employees could find each other. Furthermore, these methods must have been effective, however they worked in practice. It is telling that we do not hear complaints of a labour shortage in Rome, even when

\footnotetext{
${ }^{84}$ Noy (2000: 151).

${ }^{85}$ Granovetter (1995: 122).

${ }^{86}$ Vesp. 1.4
} 
significant manpower was required for large public building projects; indeed, Vespasian's famous refusal to adopt a labour-saving device in building as it would deprive the plebs (plebicula) of food rather suggests the opposite. ${ }^{87}$

\section{References:}

— Beard, M., North, J., and Price S. (1998). Religions of Rome. Cambridge.

- Broughton, T. R. S. (1938). 'A Greek inscription from Tarsus', American Journal of Archaeology 42.1: 55-57.

- Brunt, P. A. (1980). 'Free labour and public works at Rome', JRS 70: 81-100.

- Burt, R. (1992). Structural Holes: The Social Structure of Competition. Cambridge, Mass.

- Carcopino, J. (1941). Daily Life in the Ancient Rome: the People and the City at the Height of the Empire. Harmondsworth.

- Coarelli, F. (2000). 'Discussions, sous la presidence de J-M. Pesez', in P. Boucheron, H. Broise, and Y. Thebert (eds.), La brique antique et medievale. Rome, 371-81.

- Cuvigny, H. (1996). 'The amount of wages paid to the quarry-workers at Mons Claudianus', JRS 86: 139-45.

— Davies, J. K. (2007). 'Classical Greece: Production', in W. Scheidel, I. Morris, and R. Saller (eds.), The Cambridge Economic History of the Greco-Roman World. Cambridge, 333-361.

— DeLaine, J. (1997). The Baths of Caracalla in Rome: a study in the design, construction, and economics of large-scale building projects in imperial Rome. Portsmouth, RI.

— DeLaine, J. (2000). 'Building the Eternal City: the building industry of imperial Rome', in J. Coulston and H. Dodge (eds.), Ancient Rome: the Archaeology of the Eternal City. Oxford, 119-41.

— Fevre, R. (1992). The Sociology of Labour Markets. Hemel Hempstead.

- Finley, M. (1985). The Ancient Economy. $2^{\text {nd }}$ ed. London.

87 Suet. Vesp. 18 
— Fuks, A. (1951). 'Labour exchange in classical Athens', Eranos 49: 171-73.

— Garnsey, P. (1998). Cities, Peasants, and Food in Classical Antiquity. Cambridge.

— Graham, S. (2005). 'Of lumberjacks and brick stamps: working with the Tiber as infrastructure', in A. MacMahon and J. Price (eds.), Roman Working Lives and Urban Living. Oxford, 106-24.

- Granovetter, M. (1973). 'The strength of weak ties', American Journal of Sociology 78.6: $1360-1380$.

- Granovetter, M. (1983). 'The strength of weak ties: a network theory revisited', Sociological Theory 1: 201-33.

- Granovetter, M. (1995). Getting a Job. A Study of Contacts and Careers. $2^{\text {nd }}$ ed. Cambridge, Mass.

- Granovetter, M. (2005). 'The impact of social structure on economic outcomes', The Journal of Economic Perspectives 19.1: 33-50.

— Gruen, E. S. (2002). Diaspora: Jews amidst Greeks and Romans. Cambridge, Mass.

- Guilhembet, J. P. and Royo, M. (2008). 'L'aristocratie en ses quartiers (II' s. avant J.-C.-IIe après J.-C.)', in M. Royo, E. Huvert, and A. Bérenger (eds.), 'Rome des quartiers': des vici aux rioni. Cadres institutionnels, pratiques sociales, et requalifications entre Antiquité et époque modern. Paris, 193-227.

- Harland, P. A. (2003). Associations, Synagogues, and Congregations: Claiming a Place in Ancient Mediterranean Society. Minneapolis.

- Hawkins, C. (2006). Work in the City: Roman Artisans and the Urban Economy. PhD thesis, University of Chicago.

- Holleran, C. (2011). 'Migration and the urban economy of Rome', in Holleran, C. and A. Pudsey (eds.), Demography and the Graeco-Roman World. New Insights and Approaches. Cambridge, 155-80. 
- Holleran, C. (2012). Shopping in Ancient Rome: the Retail Trade in the Late Republic and the Principate. Oxford.

— Jones, A. H. M. (1973). The Later Roman Empire, 284-602. A Social, Economic, and Administrative Survey, 2 vols. Oxford.

— Joshel, S. R. (1992). Work, Identity, and Legal Status at Rome: a Study of the Occupational Inscriptions. Norman, Ok.

- Kalleberg, A. L. and Sorensen, A. B. (1979). 'The sociology of labour markets', Annual Review of Sociology 5: 351-79.

- Lanciani, R. (1897). The Ruins and Excavations of Ancient Rome. London.

— Le Gall, J. (1971). 'Rome ville des fainéants?', Revue des Ètudes Latines 49: 266-77.

- Lewis, N. and Reinhold, M. (1990). Roman Civilization: the Empire (Volume 2). $3^{\text {rd }}$ ed. New York.

— Liu, J. (2009). Collegia Centonariorum. The Guilds of Textile Dealers in the Roman West. Leiden.

- Lo Cascio, E. (2008). 'Vici, regiones e forme di interazione sociale nella Roman imperiale', in M. Royo, E. Huvert, and A. Bérenger (eds.), 'Rome des quartiers': des vici aux rioni. Cadres institutionnels, pratiques sociales, et requalifications entre Antiquité et époque modern. Paris, 64-76.

— Lott, J. B. (2004). The Neighbourhoods of Augustan Rome. Cambridge.

— Louis, P. (1927). Ancient Rome at Work. An Economic History of Rome from the Origins to the Empire. London.

- MacMullen, R. (1974). Roman Social Relations. 50 BC to AD 284. New Haven.

— Marett, V. (1989). Immigrants Settling in the City. Leicester.

- Meiggs, R. (1980). Roman Ostia 2nd ed. Oxford.

- Moretti, L. (1958). 'Sulle stationes municipiorum del foro Romano', Athenaeum n.s. 36: 106116. 
- Mouritsen, H. (1988). Elections, Magistrates and Municipal Elite: Studies in Pompeian Epigraphy. Rome.

- Munshi, K. (2003). 'Identification of network effects: Mexican migrants in the US labour market', Quarterly Journal of Economics 118 (2): 549-97.

— Noy, D. (2000). Foreigners at Rome: Citizens and Strangers. London.

- Ogden, D. (2001). Greek and Roman Necromancy. Princeton, NJ.

- Palmer, R. E. A. (1997). Rome and Carthage at Peace. Stuttgart.

- Patterson, J. (2006). Landscape and Cities. Rural Settlement and Civic Transformation in Early Imperial Italy. Cambridge.

- Peña, J. T. and McCallum, M. (2009). 'The production and distribution of pottery at Pompeii: a review of the evidence part 1, production', AJA 113.1: 57-79.

— Poros, M. V. (2001). 'The role of migrant networks in linking labour markets: the case of Asian Indian migration to New York and London', Global Networks 1.3: 243-60.

- Purcell, N. (1994). 'The city of Rome and the plebs urbana in the Late Republic', in J. A. Crook, A. Lintott, and B. Rawson (eds.), Cambridge Ancient History 2nd ed. Vol IX. The Last Age of the Republic 146-43 BC. Cambridge, 644-88.

— Ricci, C. (2005). Orbis in urbe. Fenomeni migratori nella Roma imperiale. Rome.

— Robinson, O. F. (1992). Ancient Rome: City Planning and Administration. London.

— Rodríguez Almeida, E. (1984). Il Monte Testaccio. Rome.

- Rosser, G. (1997). 'Crafts, guilds, and the negotiation of work in the Medieval town', $P \& P$ 154: 3-31.

— Scheidel, W. (2004). 'Human mobility in Roman Italy I: the free population', JRS 94: 1-26.

— Scheidel, W. (2005). 'Human mobility in Roman Italy II: the slave population', JRS 95:64-80.

— Scheidel, W. (2007). 'Demography', in W. Scheidel, I. Morris, and R. Saller (eds.), The Cambridge Economic History of the Greco-Roman World. Cambridge, 38-86. 
— Scheidel, W. (2012). 'Slavery', in W. Scheidel (ed.), The Cambridge Companion to the Roman Economy. Cambridge, 89-113.

— Sirks, B. (1991). Food for Rome. Amsterdam.

— Sosin, J. D. (1999). 'Tyrian stationarii at Puteoli', Tyche 14: 275-84.

— Skydsgaard, J. E. (1976). 'The disintegration of the Roman labour market and the clientele theory', in K. Ascani (ed.), Studia Romana in Honorem Petri Krarup Septuagenarii. Odense, 44-48.

— Tacoma, L. E. (2014). 'Migrant quarters in Rome', in S. Benoist and G. de Kleijn (eds.), Integration in Rome and in the Roman world : proceedings of the Tenth Workshop of the International Network Impact of Empire (Lille, June 23-25, 2011). Leiden \& Boston, 127-146.

— Tacoma, L. E. (forthcoming b). 'Networks networks everywhere. Migration, community formation, and integration in the city of Rome under the Principate'.

- Taylor, C. (2011). 'Migration and the demes of Attica', in in Holleran, C. and A. Pudsey (eds.), Demography and the Graeco-Roman World. New Insights and Approaches. Cambridge, 11734.

— Tarpin, M. (2008). 'Les vici de Rome, entre sociabilité de voisinage et organisation administrative', in M. Royo, E. Huvert, and A. Bérenger (eds.), 'Rome des quartiers': des vici aux rioni. Cadres institutionnels, pratiques sociales, et requalifications entre Antiquité et époque modern. Paris, 35-64.

— Temin, P. (2004). 'The labour market of the early Roman empire', Journal of Interdisciplinary History 34.4: 513-38.

- Temin, P. (2013). The Roman Market Economy. Princeton and Oxford.

_ Valenzuela, A. (2003). 'Day labour work', Ann.Rev.Sociol. 29: 307-33.

- Valenzuela, A, Theodore, N., Meléndez, E., and Gonzalez, A. L. (2006). 'On the corner: day labour in the United States': http://www.sscnet.ucla.edu/issr/csup/uploaded files/Natl DayLabor-On the Corner1.pdf 
- Verboven, K. (2002). The Economy of Friends. Economic Aspects of Amicitia and Patronage in the Late Republic. Brussels.

— Verboven, K. (2011). 'Resident aliens and translocal merchant collegia in the Roman empire', in O. Hekster and T. Kaizer (eds.), Frontiers in the Roman World: Proceedings of the Ninth Workshop of the International Network Impact of Empire (Durham, 16-19 April, 2009). Leiden, 335-48.

— Wallace-Hadrill, A. (2008). Rome's Cultural Revolution. Cambridge.

- Winter, J. (1993). London's Teeming Streets 1830-1914. London and New York.

— Yakubovich, V. (2005). 'Weak ties, information, and influence: How workers find jobs in a local Russian labor market', American Sociological Review 70.3: 408-421. 